$$
\begin{aligned}
& \text { 固／液界面衝突解析モデルによるピッティング損傷評価 }{ }^{\dagger}
\end{aligned}
$$

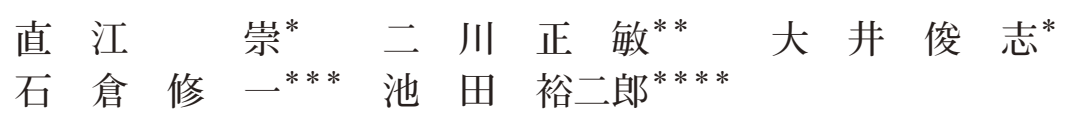

\title{
Pitting Damage Evaluation by Liquid/Solid Interface Impact Analysis
}

by

\author{
Takashi NAOE ${ }^{*}$, Masatoshi Futakawa ${ }^{* *}$, Toshiyuki Oı ${ }^{*}$, \\ Shuichi IshIKURA ${ }^{* * *}$ and Yujiro IKEDA ${ }^{* * *}$
}

\begin{abstract}
High power spallation targets for neutron sources are being developed in the world. Mercury target will be installed at the material science and life facility in J-PARC, which will promoted innovative science. The mercury target is subject to the pressure wave caused by the proton bombarding in the mercury. The pressure wave propagation induces the cavitation in mercury that imposes localized impact damage on the target vessel. The impact erosion is a critical issue to decide the lifetime of the target. The electro Magnetic IMpact Testing Machine, MIMTM, was developed to reproduce the localized impact erosion damage and evaluate the damage formation. Additionally, droplet impact analysis was carried out to investigate the correlation between isolate pit profile and micro-jet velocity. We confirmed that value of depth/radius was able to estimate micro-jet velocity. And the velocity at 560W in MIMTM was estimated to be 225 $325 \mathrm{~m} / \mathrm{s}$. Furthermore, surface-hardening treatments inhibited pit formation in plastic deformation.
\end{abstract}

Key words : Spallation target, Mercury, Cavitation erosion, Pitting damage, Droplet

\section{1 緒 論}

MW 級の核破砕中性子源として開発が進められている JSNS (Japan Spallation Neutron Source) では，中性子収率 及び，冷却性の観点から液体金属である水銀をターゲッ ト材として用いる. 大強度の陽子ビームがターゲット材に 入射すると, 核破砕反応による中性子の発生と共に, 水 銀の急激な発熱によりターゲット容器内では圧力波が生 じる．この圧力波が水銀中を伝ぱする過程で水銀とター ゲット容器の界面で負圧が発生する。この負圧により容 器内壁では, キャビテーションの発生・崩壊に伴うピッ ティング損傷が懸念される。ピッティング損傷による容器 壁面の壊食は, 中性子源の高出力化及びターゲット容器 の健全性を確保する上で重要な課題である.1)これまでに著 者らは，ホプキンソン棒衝撃原理 SHPB (Split Hopkinson Pressure Bar) に基づいた平面歪み波入射実験を表面硬 化処理材に対して行い，壊食初期の抵抗は表面の硬度と 良い相関があることを示した。2 また，ターゲット容器内 で発生する負圧を再現した電磁式衝撃圧負荷試験装置 MIMTM (Magnetic IMpact Testing Machine) を用いた 損傷実験を行い，損傷の負荷圧力及び材料依存性を定量 的に評価した.3)これらの知見より，損傷の程度及び壊食 量を定量的に評価できることが分かった。

キャビテーション現象でマイクロピットが形成される メカニズムは完全には解明されていない. Challier らは, 気泡力学の観点からの考察 ${ }^{4)}$ Patella らは, 圧力波の衝突
による数值解析と, 実験結果を比較し, ピット形成のパ ワー依存性を示している.5)一方，著者らは音響振動計測 により抽出したマイクロバブルの崩壊に起因すると考え られる衝撃力に関する情報と損傷量との間に相関がある ことを見出した。本本報では，ピッティング損傷を個々の ピット形成というミクロな観点から評価するために，ピッ ティング損傷の主因と考えられるマイクロバブル崩壊時 に発生するマイクロジェットを模擬した液滴衝突解析を 行い, MIMTM による損傷実験より得たピット形状との 比較から，ピット形成時に発生する衝撃力について考察 した.

\section{2 実験}

\section{$2 \cdot 1$ 試験装置}

実験には，陽子ビーム入射時に発生する接液界面での 負圧を再現できる電磁式衝撃圧負荷試験装置（以下 MIMTM）を用いた。Fig. 1 に MIMTM の衝撃圧負荷 部に設置される試験体を示す。水銀を充填した SUS316 製の円筒容器下部を試験片により封じ，試験片下端に固 定したアルミ合金製のストライカーを電磁力により高速 で変位させて接液界面に負圧を生じさせる構造である。 衝撃圧は, 電磁コイルへの入力パワー（電圧 $\times$ 電流）に より制御した。試験片の振動振幅は最大で $0.4 \mathrm{~mm}$ であ る. MIMTM による衝撃圧入力周期は可変であるが, 本 実験では，JSNSの陽子ビーム入射周期である $40 \mathrm{~ms}$ $(25 \mathrm{~Hz})$ 一定とした.

$\dagger \quad$ 原稿受理 平成 17 年 4 月 20 日 Received Apr. 20, 2005

* 茨城大学大学院 ７316-8511 日立市中成沢町, Graduate Student, Ibaraki Univ., Nakanarusawa-cho, Hitachi, 316-8511

** 正 会 員 日本原子力研究所 †319-1195 茨城県那珂郡東海村白方白根, JAERI, Naka-gun, Ibaraki, 319-1195

$* * *$ 日本原子力研究所 ₹311-1394 茨城県東茨城郡大洗町成田町新堀, JAERI, Higashiibaraki-gun, Ibaraki, 311-1394

$* * * *$ 日本原子力研究所 $\quad \overline{7} 319-1195$ 茨城県那珂郡東海村白方白根, JAERI, Naka-gun, Ibaraki, 319-1195 


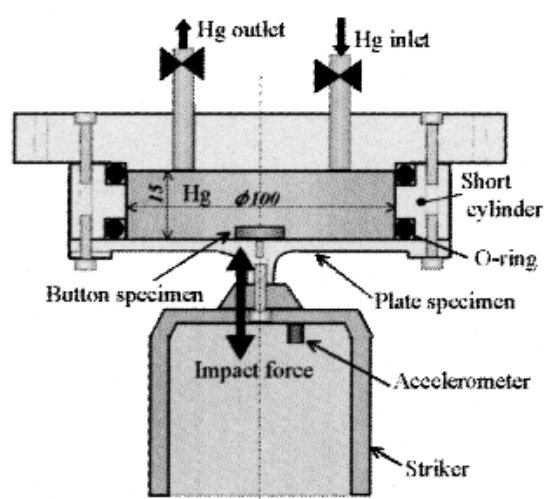

Fig. 1. Mercury chamber in MIMTM.

\section{$2 \cdot 2$ 試験片}

試験片は 2 種類ある。すなわち, 直径 $100 \mathrm{~mm}$, 厚さ $1 \mathrm{~mm}$ の円板及びその中心にネジ止めした直径 $12 \mathrm{~mm}$ ，厚 さ2.5mm のボタン型である，材質は，ターゲット容器構 造材の候補材である SUS316L 及びその表面にプラズマ窒 化処理 ${ }^{7)}$ を施したもの，浸炭処理の一種である Kolsterise 処理 ${ }^{8)}$ 施したものである。試験片断面の硬度分布を Fig. 2 に示す．表層の硬度はプラズマ窒化 > Kolsterise > SUS316Lであり，硬化層厚さは Kolsterise で約 $30 \mu \mathrm{m}$, プラズマ窒化で約 $20 \mu \mathrm{m}$ であり厚さ方向に対して硬度の 分布を有する。

\section{$2 \cdot 3$ 実験方法}

衝撃圧の負荷条件及び材料表面の力学特性がピット形 成に及ぼす影響を評価するために，以下に示す条件で衝 撃負荷試験を行った。

\section{(a) 入力パワー依存性}

負荷圧力を決定する入力パワーの影響を評価するため にSUS316L の円板試験片を用いて，入力パワーを $185 \mathrm{~W}$ から $690 \mathrm{~W}$ の範讲で変化させて試験を行った。衝撃回数 は，これまでの実験から，ピット間の干渉が無く独独立 したピット痕が観測でき, 損傷の程度を明確に判断でき る衝撃回数である $10^{3}$ 回とした。

(b) 材料依存性

SUS316L，Kolsterise，プラズマ窒化のボタン型試験 片を用いて，入力パワーを $1 \mathrm{MW}$ 相当の陽子ビーム入射 実験時に観測された損傷を再現した $560 \mathrm{~W}$ 一定とした。

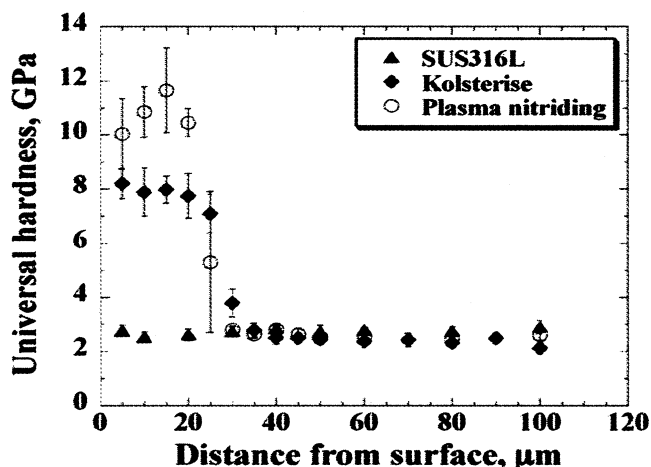

Fig. 2. Hardness distribution along distance from surface of specimens.
衝撃回数は, SUS316Lのボタン型試験片において独立し たピット痕を確認できる $10^{4}$ 回とした。

両試験ともに，試験後にアセトン中にて超音波洗浄を 施し，水銀を除去した後，レーザー顕微鏡により損傷面 の観察及びピット深さの計測を行った。

\section{$3 \cdot 1$ 固/液衝突モデル}

3 固/液衝突解析

壁面でのキャビテーションの崩壊によるピッティング 損傷は，気泡が壁面の抵抗により非球形に崩壊するマイ クロジェット，壁面から離れたバブルの崩壊に伴い発生 する衝撃波に誘発されるウルトラジェットによると考え られる.9)試験条件や気泡の位置によって両者が混在する 場合もある，本報では，壁面に付着している場合を仮定 し，マイクロジェットの衝突によるピット形成を，マイ クロジェットを模擬した液滴衝突解析を行った。

解析には陽解法によるオイラー/ラグランジュの相互作 用を扱える 2 次元衝撃解析コードAUTODYN-2D ${ }^{10)}$ を用 いた。解析モデルを Fig. 3 に示す。 円板（ラグランジュ 形式）の中心にマイクロジェットを想定した水銀球（才 イラー形式）を初速 $v_{0}$ で衝突させる軸対称モデルとした。

固体壁の境界条件は，水銀が衝突する面を自由境界面 とし，その他の面は完全固定とした。 また，板厚は解析 結果に影響がない十分な厚さを有する。

\section{$3 \cdot 2$ 水銀と固体壁の構成式}

(a) 水銀の状態方程式

水銀の状態方程式には, Rankine-Hugoniot の関係式を 基に，衝撃波の状態方程式を組み合わせて，基準ウゴニ 才曲線からのエネルギー変化 $\Delta E$ を伴う一般状態方程式 に拡張し，エネルギー変化の一次項で近似した次式を用 いた.11)

$$
p=p_{H}+\Gamma \rho\left(E-E_{H}\right)
$$

ここで， $\Gamma$ は Mie-Gruneisen 係数， $E$ は内部エネルギー, 添え字 $H$ は実験で求められる基準ウゴニオ曲線での值を 示す，本解析では，水銀の発熱等によるエネルギーの変 化が無いと仮定し，式 (1)の第二項は無視できるとした. 式 (1)中の $p_{H}$ は, 音速 $c_{0}$, 衝撃波速度を決めるパラメー 夕 $s$, 密度 $\rho$ の関数であり, 次式 ${ }^{12)}$ で表される.

$$
p_{H}=\frac{\rho_{0} c_{0}^{2} \mu(1+\mu)}{[1-(s-1) \mu]^{2}}, \quad \mu=\frac{\rho-\rho_{0}}{\rho_{0}}
$$

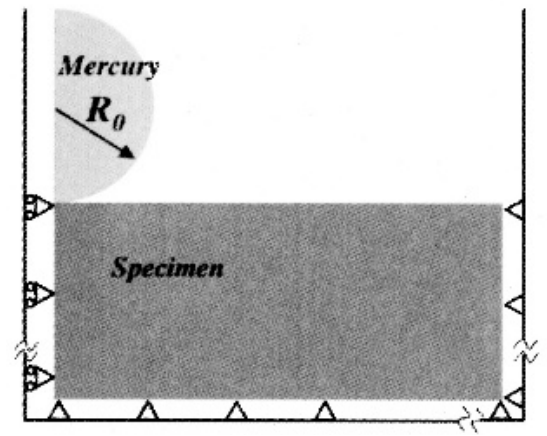

Fig. 3. Model for droplet impact analysis. 
ここで， $\rho_{0}$ は初期密度である. 水銀の物性值は, $\rho_{0}=$ $13.54 \times 10^{3} \mathrm{~kg} / \mathrm{m}^{3}, \Gamma=1.96, c_{0}=1490 \mathrm{~m} / \mathrm{s}, s=2.047$ と した.13)

(b) 固体壁の材料構成式

固体壁の動的構成式には, Johnson-Cook モデル ${ }^{14)}$ 用いた. 流動応力 $\sigma_{y}$ (降伏応力) は次式で与えられる.

$$
\begin{aligned}
& \sigma_{y}=\left[A+B \varepsilon_{p}^{n}\right]\left[1+C \log \dot{\varepsilon}_{p}\right]\left[1-T_{H}^{m}\right] \\
& T_{H}=\left(T-T_{R}\right) /\left(T_{m}-T_{R}\right)
\end{aligned}
$$

ここで, $\varepsilon_{p}$ は塑性歪， $\dot{\varepsilon}_{p}$ は塑性歪速度，Tは金属温度， $T_{R}$ は室温, $T_{m}$ は金属の融解温度である。また， $A$ は静 的降伏応力, $B$ は塑性歪硬化係数, $n$ は加工硬化指数, $C$ は歪速度硬化係数, $m$ は熱軟化指数である. 本解析で は，温度依存性は無視できるものと仮定した。また， $B$ は SUS316L の静的引張り試験結果 ${ }^{15)}$ から得た線形硬化係数 を塑性歪硬化係数として近似的に設定した。 歪速度硬化 を考慮した解析を行い, 歪速度によるピット形状の変化 は殆ど見られなかったため, $C=0$ として解析を行った。

(c) 表面硬化処理材の材料構成式の同定

表面硬化処理材は, 硬化厚さが数十 $\mu \mathrm{m}$ と極めて薄く, 従来の単軸引張り試験などから材料構成式を規定するこ とは困難である。従って，本解析では，表面硬化処理層 の材料定数は，著者らが考案した微小押込み試験の逆解 析 ${ }^{15)}$ を用いることにより同定した值とした。以下に逆解 析手法を簡潔に述べる.

静的な材料構成式として次式の関係を仮定する.

$$
\begin{array}{ll}
\sigma=E \varepsilon & \sigma \leq \sigma_{y} \\
\sigma=A\left(\varepsilon_{0}+\varepsilon\right), \varepsilon_{0}=\left(\sigma_{y} / A\right)-\left(\sigma_{y} / E\right) & \sigma \geq \sigma_{y}
\end{array}
$$

ここで, $\sigma_{y}$ は静的降伏応力, $E$ はヤング率, $A$ は加工硬 化係数である. 同定する材料定数は $\sigma_{y}$ と $A$ である. 球 状圧子を用いた微小押込み試験により荷重一深さ曲線を 測定し，上式を考慮した FEM モデルにより微小押込み 試験を再現し，荷重一深さ曲線に対して，カルマンフィ ルタを用いた逆解析により材料定数を同定した。ここで は, 表面硬化処理材の厚さ方向に対する分布を考慮しな い. 詳細は既報 ${ }^{16)}$ を参照されたい。

SUS316L 及び同定した SUS316L 材の表面硬化処理層 の液適衝突解析条件を Table I に示す。また, 初期密度 $\rho_{0}=7.89 \times 10^{9} \mathrm{~kg} / \mathrm{m}^{3}$, 室温 $T_{R}=300 \mathrm{~K}$ は SUS316L の值 を用い, 温度依存性は無視した。

$$
4 \text { 結果 }
$$

\section{$4 \cdot 1$ 損傷形態}

円板試験片を用いて入力パワーを変化させた場合の試 験片表面写真及びピット深さ分布を Fig. 4, Fig. 5 に示 す. 入力パワーの増加に伴い，ピット形状が明確となる.

Table I. Mechanical properties in droplet analysis.

\begin{tabular}{|c|c|c|c|}
\hline Material & $\sigma_{90}[\mathrm{MPa}]$ & $B[\mathrm{MPa} / \varepsilon]$ & $V_{0}[\mathrm{~m} / \mathrm{s}]$ \\
\hline SUS316L & 203 & 958 & $0-350$ \\
\hline $\begin{array}{c}\text { Plasma } \\
\text { Nitriding }\end{array}$ & 2247 & 1390 & $0-500$ \\
\hline Kolsterise & 1615 & 1157 & $0-500$ \\
\hline
\end{tabular}

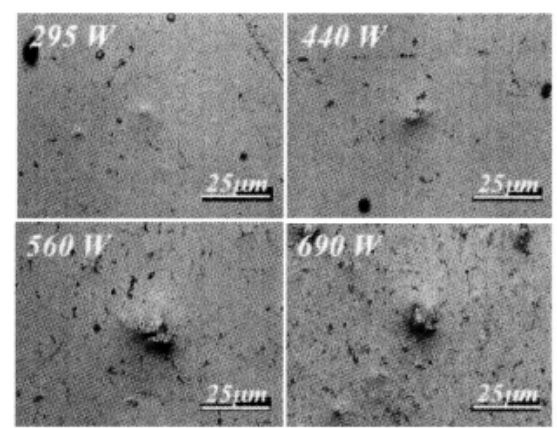

Fig. 4. Micrographs of pits in various powers for SUS316L.

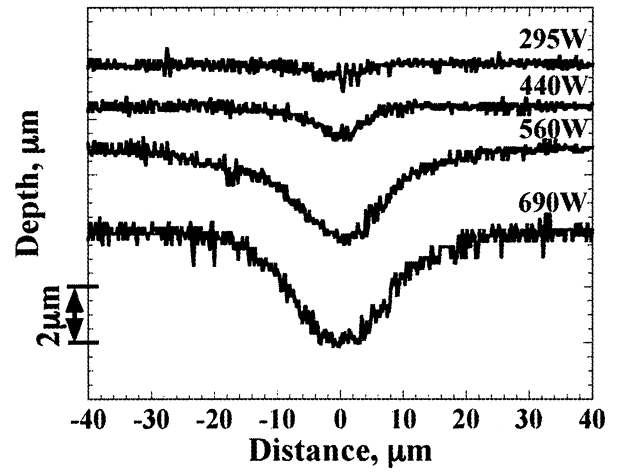

Fig. 5. Depth profiles of pits in various powers for SUS316L.

すなわち, ピット径, 深さ共に増加し, ピット形状のパ ワー依存性を確認できる。また，185Wでは，ピットを 確認することができなかった，従って，ピット形成に要 する衝撃力には下限值が存在することが分かる。入力パ ワーの変化に対するピット深さ $d$, 半径 $r$ の変化を Fig. 6 に示す。ここで, $d$ および $r$ は 20 箇所の平均值である. $200 \sim 560 \mathrm{~W}$ の範囲では入力パワーの増加に伴い $d, r$ 共 に増加するが, $560 \mathrm{~W}$ 以上では顕著な増加は無い.

ボタン型試験片を用いた入力パワー $560 \mathrm{~W}, 10^{4}$ 回試験 後では, SUS316L 及び Kolsterise ではピットを確認でき たが，プラズマ窒化では確認できなかった。試料表面を 硬化させることにより損傷が抑制されたことを示す。さ らに，プラズマ窒化については独立したピット形状を観 察するために，衝撃回数を $10^{6}$ 回まで増加させた。レー

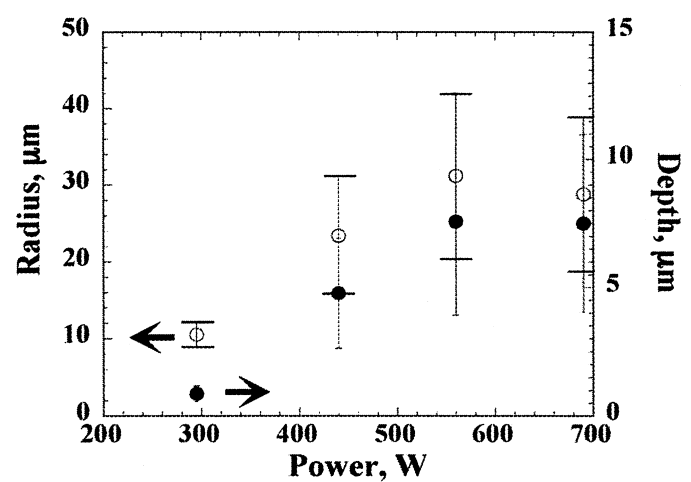

Fig. 6. Effect of input power and material properties on depth/radius. 
ザー顕微鏡により計測した独立したピット写真及びピッ 卜形状を Fig. 7，8 に示す. SUS316L 及び Klosterise で は，塑性変形に伴うすべり線が確認できた。一方，プラ ズマ窒化は塑性変形ではなく，一部が崩落した様な形状 であった。高サイクルの衝撃による疲労破壊の可能性が ある. Fig. 9 に示すのは，ビッカース圧子を用いて試験 荷重 $49 \mathrm{~N}$ で圧痕をつけた試料表面の写真である。 SUS316L 及び Kolsterise では塑性変形によるすべり線が 見られる。また，Kolsterise，プラズマ窒化では，圧痕周 囲に亀裂が見られ，その程度はプラズマ窒化で顕著であ る。したがって, 特にプラズマ窒化の場合は, 高硬度で あるが脆く，ピット形成時にも亀裂や崩落が生じやすいこ とが分かる.

\section{$4 \cdot 2$ 固 / 液界面衝突解析}

固体壁をSUS316L として衝突速度を変化させた場合 のピット形状を Fig. 10 に示す。ここで，半径 $R$ 及び深 さ $D$ は水銀球の半径 $r_{0}$ で規格化した。衝突速度の増加 に伴い, $R, D$ 共に増加する。また，衝突速度 $225 \mathrm{~m} / \mathrm{s}$ 以 上になると明確なパイルアップが見られる．同様にして， Kolsterise，プラズマ窒化のピット形状を Fig. 11，12 に 示す。ピット周囲のパイルアップはほとんど見られず， SUS316L と同じ速度での変形量が極めて少ないことが分 かる.
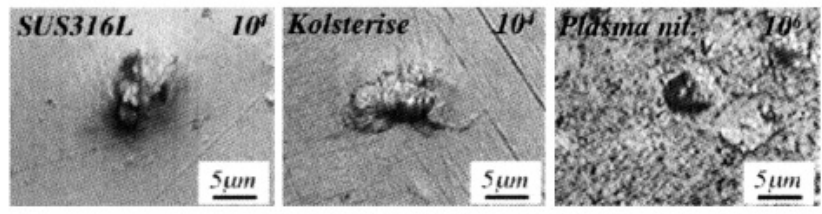

Fig. 7. Micrographs of pits after $10^{4}$ impacts for SUS316 and Kolsterise and $10^{6}$ impacts for plasma nitriding.

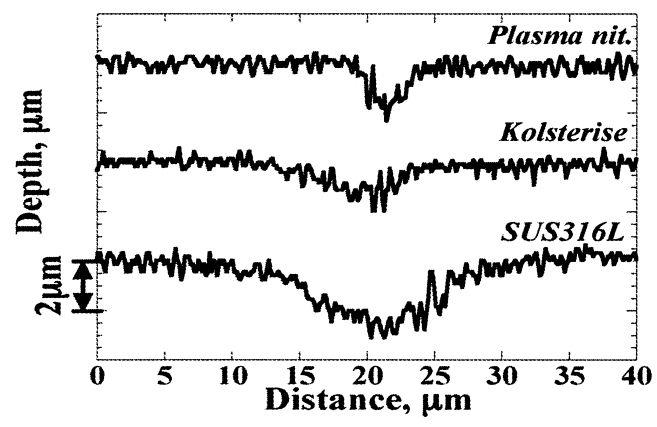

Fig. 8. Depth profile of pits after $10^{4}$ impacts for SUS316L and Kolsterise and $10^{6}$ impacts for plasma nitriding at $560 \mathrm{~W}$.

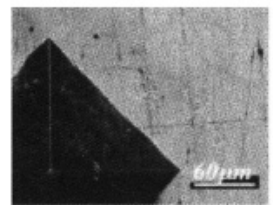

SUS316L

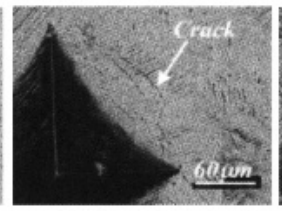

Kolsterise

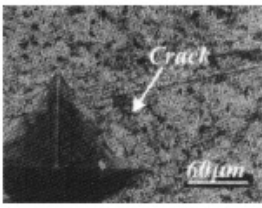

Plasma nitriding
Fig. 9. Micrographs of plastic deformation around large indent.

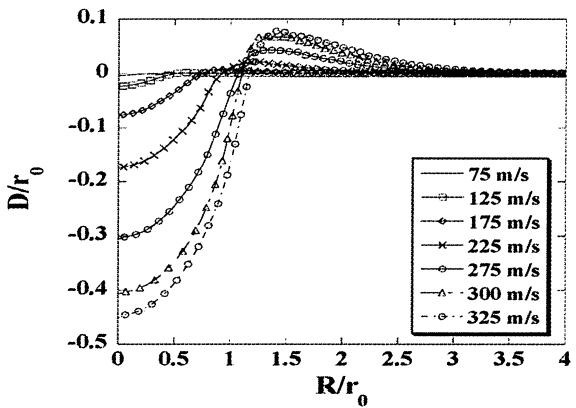

Fig. 10. Depth profile of pits in various droplet velocities for SUS316L.

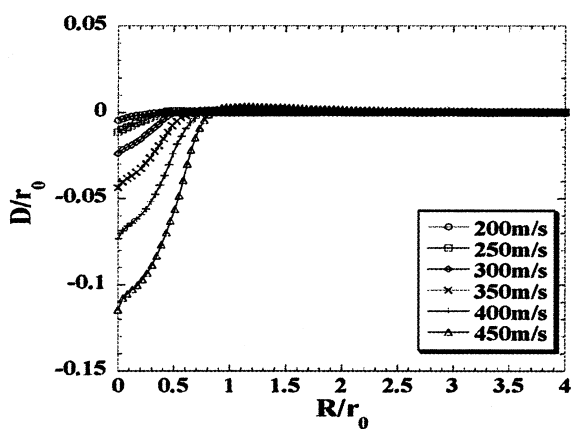

Fig. 11. Depth profile of pits in various droplet velocity for Kolsterise.

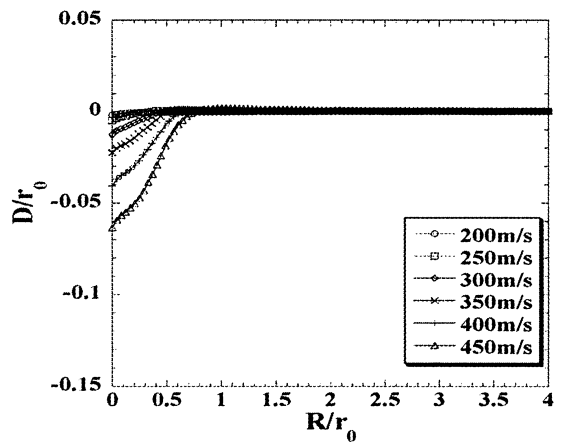

Fig. 12. Depth profile of pits in various droplet velocity for Plasma nitriding.

ピット半径 $R$ 及び深さ $D$ を, $D / R$ で無次元化して損 傷を評価するパラメータとして用いた。衝突速度による $D / R$ の変化を Fig. 13 に示す. 衝突速度が低い領域で は, 固体壁の変形は弾性領域内で収まりピットは形成さ れないが，衝突速度の増加に伴い $D / R$ は増加することが 分かる。また，降伏応力の高い表面硬化処理を固体壁に 用いた場合は, SUS316L と比較して $D / R$ は小さく，ピッ トが浅く広くなることが分かる。また，ピットが形成さ れない衝突速度の下限值は上昇する.

$$
5 \text { 考察 }
$$

\section{$5 \cdot 1$ マイクロジェット衝突速度の推定}

Fig. 13 に示すように, ピット形状 $(D / R)$ とマイクロ ジェット衝突速度には良い相関が認められる。すなわち， ピット形状からピット形成時に負荷したマイクロジェッ 卜衝突速度が推定できる。そこで，各入力パワー条件下 


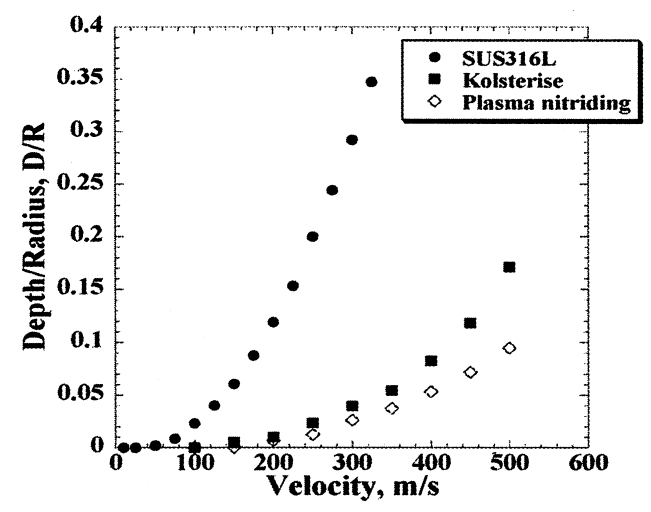

Fig. 13. Relationship between analytical $\mathrm{D} / \mathrm{R}$ value and droplet velocity.

で計測した SUS316L 円板試験片の $d / r$ 值をパワーに対 しプロットした結果を Fig. 14 に示す. 入力パワーと共 に $d / r$ は増加する。したがって, Fig. 13 と Fig. 14 の関 係から各パワー条件に対するマイクロジェット衝突速度 を得ることができる。すなわち, Fig. 13 の結果から $D / R$ と衝突速度の関係を表す回帰曲線を求め, 光れに実 測した $d / r$ を代入することにより衝突速度と入力パワー の関係を Fig. 15 のように得た. MIMTM の標準パワーで ある $560 \mathrm{~W}$ におけるマイクロジェット衝突速度は 225 $325 \mathrm{~m} / \mathrm{s}$ の間にあることが推測できる.

また, 推定した入力パワーと衝突速度の関係を用いて マイクロジェットが固体壁に衝突し, ウォータハンマ効 果により生じる圧力 $p$ を次式により算出した。

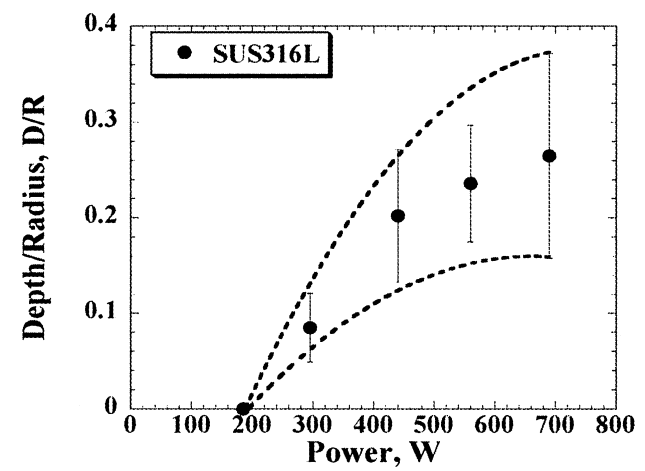

Fig. 14. D/R values against input power of MIMTM.

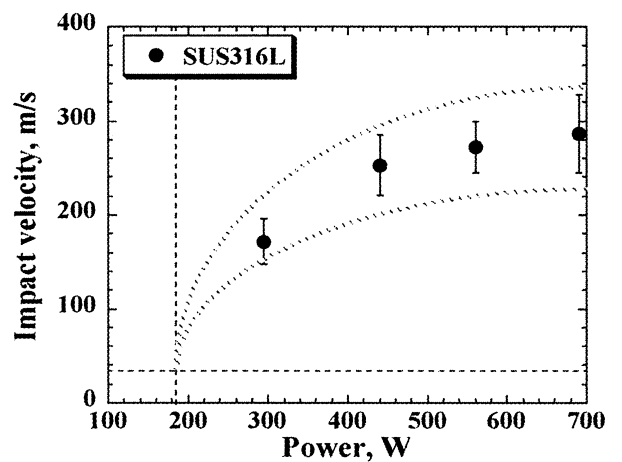

Fig. 15. Comparison of $\mathrm{D} / \mathrm{R}$ values of MIMTM at $560 \mathrm{~W}$ and analysis.

$$
p=\rho C v
$$

ここで, $\rho$ は水銀の密度, $C$ は音速, $v$ は各パワーでの衝突 速度である。算出した入力パワーによる衝撃圧力変化及 び液適衝突解析時に固体壁に発生する最大圧力を Fig. 16 に示す．算出した衝撃圧力は解析結果よりも若干高くな るが，入力パワーと共に増加し， $560 \mathrm{~W} て ゙ 5 \mathrm{GPa}$ 前後で あることが分かる。

\section{$5 \cdot 2$ 水銀滴形状の影響}

実測した 560W 試験時の SUS316L のピット形状及び, 推定した最大衝突速度 $300 \mathrm{~m} / \mathrm{s}$ におけるピット形状を比 較した結果を Fig. 17 に示す。ここで，半径 $R$ 及び深さ $D$ は，それぞれの最大值で規格化した。実測したピット 形状と比較してピット中心にかけての勾配及びパイルアッ プに差が見られる。旮こで，水銀の形状を変化させた場 合のピット形状の変化を比較した. Fig. 18 に示すのは, 半径 $r_{0}$ の球, 底面の半径が $r_{0}$ の頂角 60 度の円錐, 底面 の半径が $r_{0}$ の円錐として衝突速度 $300 \mathrm{~m} / \mathrm{s}$ で衝突させた 場合のピット形状を $r_{0}$ で規格化したものである. 水銀の 形状が円柱 $\rightarrow$ 球 $\rightarrow$ 円錐となるに従い実験結果に近づくこ とが分かる. また, 各衝突速度で水銀の形状を変化させた 場合の $D / R$ を Fig. 19 に示す. 形状を変化させても $D / R$ には大きな変化は見られず, 形状依存性が無く, ピッティ ング損傷評価のパラメータとして $D / R$ が有効であるとい える。

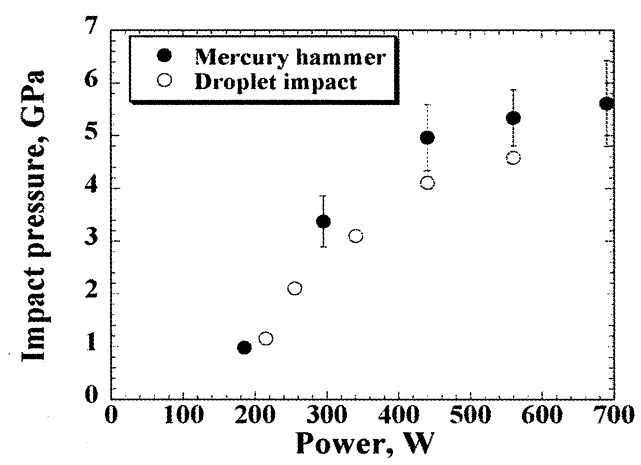

Fig. 16. Relationship between impact pressure and input power.

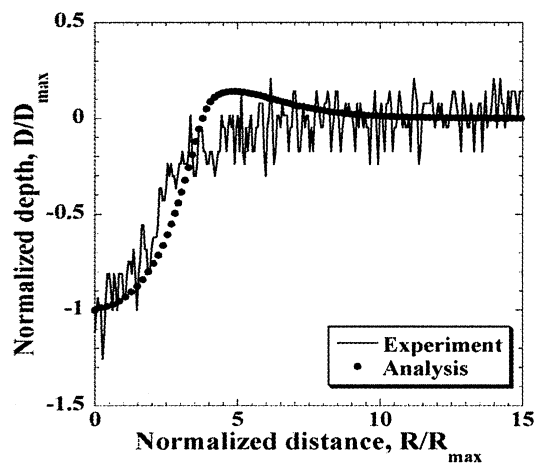

Fig. 17. Comparison of the pit profile of experiment and analysis in SUS316L at 560W. 


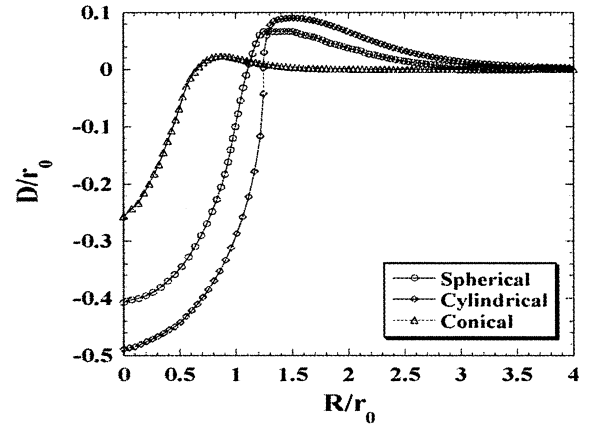

Fig. 18. Depth profiles for three types of droplet at $300 \mathrm{~m} / \mathrm{s}$.

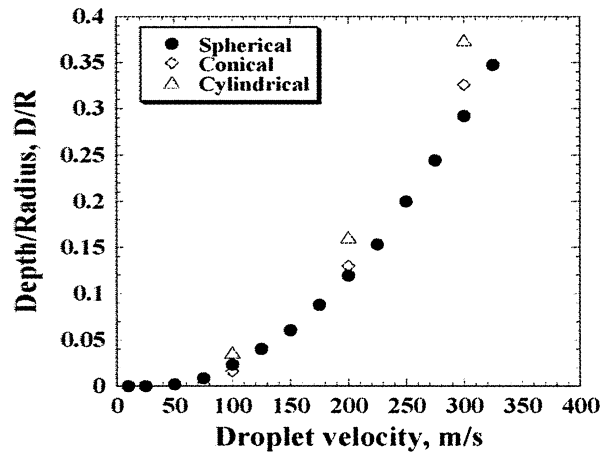

Fig. 19. Droplet profile dependency on $D / R$ value.

\section{$5 \cdot 3$ 硬化層厚さの影響}

硬化表層厚さがピット形成に及ぼす影響を調べるため に, 固体壁を表層 + 基材の 2 層モデルとし, 硬化層厚 さによるピット形状，応力分布の変化を調べた。ここで， 衝突速度 $v_{0}$ は， $300 \mathrm{~m} / \mathrm{s}$ 一定とした。

硬化層は Kolsterise として, 水銀球半径 $r_{0}$ 一定で硬化 層厚さ $t$ を変化させた場合のピット形状の変化を Fig. 20 に示す，ここで，深さ，半径及び硬化層厚さは， $r_{0}$ で規 格化した．硬化層厚さが水銀球の径に対して二倍以上に なるとピット形状には影響が現れないことが分かる。ま た，ピット周囲のせん断応力分布を Fig. 21 に示す。硬 化層と基材の界面では，せん断応力が生じている。また， それは硬化層が薄いほど顕著に現れることが分かる。

更に，表面効果処理材は厚さ方向に対して硬度の分布 (Fig. 2) に見られる様な力学特性分布を有していると考え られる。厚さ方向の力学特性分布によるピットプロファイ ル , 応力分布を二層モデルと比較した. 硬化層は $t / r_{0}=1$

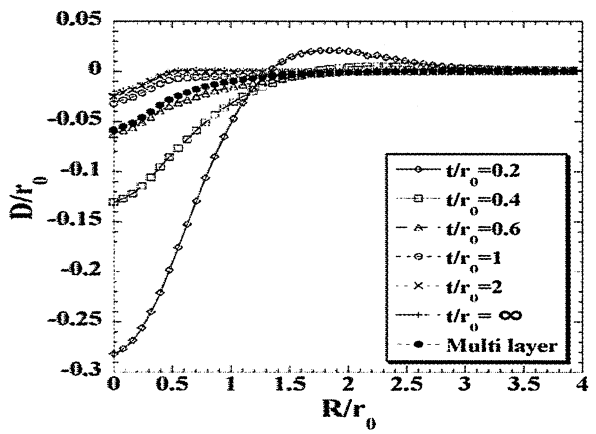

Fig. 20. Hardening layer dependency at $300 \mathrm{~m} / \mathrm{s}$.

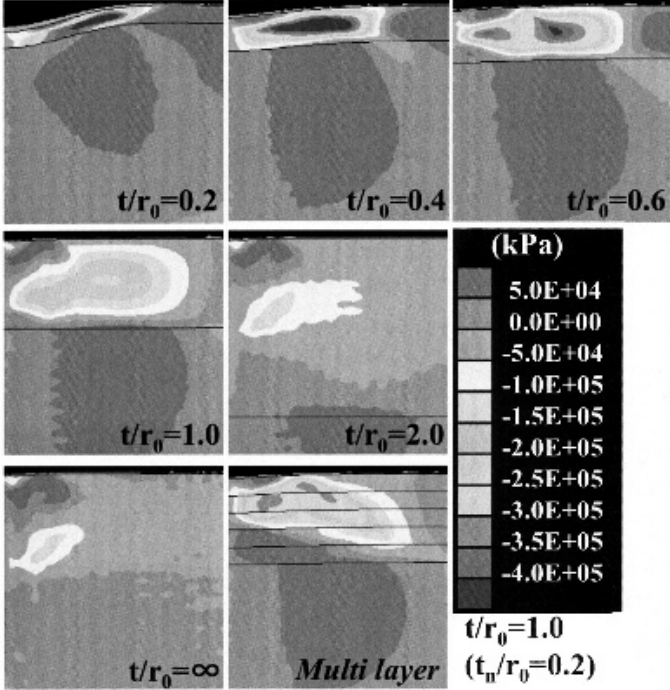

Fig. 21. Share stress distributions for 2-layer models.

までを 5 層に分割し，表層を Kolsterise とし，降伏応力 にステップ状の分布を持たせた。衝突速度は 2 層モデル と同一である $300 \mathrm{~m} / \mathrm{s}$ とした。 ピットプロファイル及び せん断応力分布を Fig. 20，21にあわせてプロットする. ピットプロファイルは硬化層厚さが薄い二層モデルと同 様な形状を示すが，応力分布は二層モデルと比較して， 硬化層との界面に生じるせん断応力が小さくなっている ことがわかる，硬化層に力学特性分布があることで, ピッ ト形成時に生じる基材との界面でのせん断応力を抑制し， 剥離が起こりにくくなることが期待できる。また，硬化 層の厚さを変化させた場合の硬化層及び基材との界面で のせん断応力の変化を Fig. 22 に示す。ここで, 衝突速 度せん断応力は引張りを正とした。硬化層及び界面での せん断応力は, 硬化層厚さの増加と供に減少する。また, Koslterise と窒化处理では, 硬化層でのせん断応力に差 が見られた。しかし，両者とも硬化層厚さが水銀球径に 対して 2 倍以上あれば界面でのせん断応力を軽減するこ とができる。

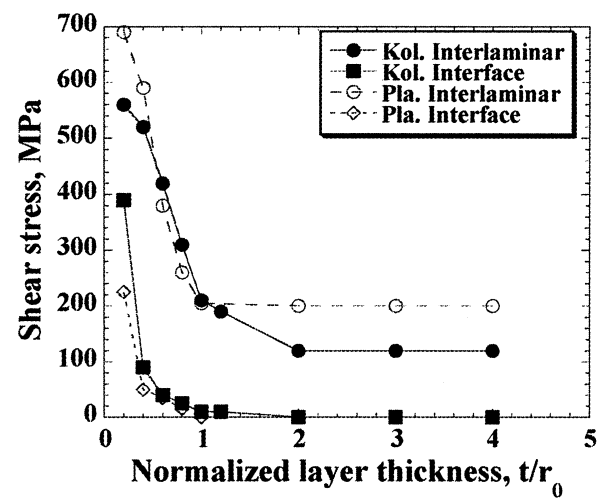

Fig. 22. Relationship between shear stress and thickness of the hardening layer in interlaminar and interface. 


\section{6 結}

\section{論}

キャビテーションの崩壊時に発生するピッティング損 傷の主因と考えられるマイクロジェットを模擬した固／ 液界面衝突解析解析を行い, 電磁式衝撃圧力負荷試験装 置 (MIMTM) を用いたピッティング損傷実験との比較 を行った。 ピット形状から測定したピット深さ／半径は マイクロジェットの形状, 大きさに関わりなくピッティ ング損傷を評価可能なパラメータであることを示し，陽 子ビーム入射時の損傷を再現した MIMTM の入力パワー 560W でのマイクロジェット速度は約 $300 \mathrm{~m} / \mathrm{s}$ であるこ とを推定した。 また, 表面硬化によりピットを形成する 衝撃力の下限值は上昇するが, 基材との界面のせん断の 問題により剥離が生じる可能性があること, 硬化層厚さ を増加させることによりそれを抑制できることを示した。

な打, 本研究は, 文部科学省科学研究費補助金（基盤 研究 B : No. 17360085）の一部を用いて行われた.

\section{参 考 文 献}

1) N. Watanabe, Rep. Prog. Phys., 66, 339 (2003).

2 ) M. Futakawa, T. Naoe, H. Kogawa, S. Ishikura and H. Date, J. Soc. Mater. Sci., Jpn., 53, 283 (2004).

3 ) M. Futakawa, T. Naoe, H. Kogawa, C. C. Tsai and Y. Ikeda, J. Nucl. Sci. Tech., 40, 895 (2003).

4 ) G. Challier and R. F. Patella, proc. ASME Fl. Eng. Summer Conf., FEDSM 2000-11037 (2000).

5 ) R. F. Patella and J. L. Reboud, J. Fl. Eng., 120, 335 (1998).
$6)$ T. Naoe, M. Futakawa, T. Koyama, H. Kogawa, Y. Ikeda, J. JSEM, 5-3 (2005) to be published.

7 ) T. Hirohata, "Ion nitriding method (in Japanese)", p.5 (1999) NDK, Incorporated.

$8)$ T. Bell and C. X. Li, Adv. Matter. Process, June, 49 (2002).

9 ) Y. Kato, “Cavitation (in Japanese)”, p.203 (1999) Maki Shoten Publishing.

10) Century Dynamics, inc. "AUTODYN Theory Manual, Ver.4.1”, p.25 (2000) Century Dynamics, inc.

11) J. A. Zukas, W. P. Walters, "Explosive Effects and Applications", p.91 (1998) Springer-Verag New York, USA.

12) S. Ishikura, H. Kogawa, M. Futakawa, M. Kaminaga, R. Hino and M. Saito, J. At. Energy Soc. Jpn., 3, 59 (2004).

13) Group GMX-6, "Selected Hugoniots”, LA-4167-MS (1969) Los Alamos Scientific Lab.

14) T. Ikushima, "Material database for impact analysis (in Japanese)” JAERI-M 88-193, Japan Atomic Energy Research Institute.

15) G. R. Johnson, W. H. Cook, A Constitutive Model and Data for Metals Subjected to Large Strains, High Strain Rates and High Temperatures, Presented at the Seventh International Symposium on Ballistics, The Hague, The Netherlands, April (1983).

16) M. Futakawa, T. Wakui, T. Naoe and I. Ioka, J. JSEM, 4, 222 (2004). 